Standard language in urban rap

Social media, linguistic practice and ethnographic context

Stæhr, Andreas; Madsen, Lian Malai

Published in:

Language \& Communication

Publication date:

2015

Document version

Publisher's PDF, also known as Version of record

Citation for published version (APA):

Stæhr, A., \& Madsen, L. M. (2015). Standard language in urban rap: Social media, linguistic practice and ethnographic context. Language \& Communication, 40, 67-81.

http://curis.ku.dk/admin/files/153780831/Standard_language_in_urban_rap_St_hr_Madsen_2015.pdf 


\title{
Standard language in urban rap - Social media, linguistic practice and ethnographic context
}

\author{
Andreas Stæhr ${ }^{\mathrm{a}, *}$, Lian Malai Madsen ${ }^{\mathrm{b}}$ \\ ${ }^{a}$ University of Copenhagen, LANCHART Center, Njalsgade 120, 2300 KBH S, Denmark \\ ${ }^{\mathrm{b}}$ University of Copenhagen, Department of Scandinavian Studies and Linguistics, Njalsgade 120, 2300 KBH S, Denmark
}

\section{A R T I C L E I N F O}

\section{Article history:}

Available online 30 January 2015

\section{Keywords:}

CMC

Language in hip hop

Linguistic ethnography

Language ideologies

Indexicality

\begin{abstract}
A B S T R A C T
This article focuses on a case that compared to previous studies of hip hop language, is surprising; a group of adolescents in Copenhagen increasingly use more monolingual, standard linguistic practices in their hip hop productions on YouTube. We argue that to fully understand this development, it is necessary to take into account the local, sociocultural meanings given to particular linguistic resources, and that this cannot be fully captured without attention to the ethnographic and sociolinguistic context. We find that the hip hop language and literacy practices in this context are related to both traditional educational norms and artistic aspirations.
\end{abstract}

(c) 2015 Elsevier Ltd. All rights reserved.

\section{Introduction}

The linguistic and literacy practices of hip hop youth are by now well-studied in sociolinguistics (e.g. Androutsopoulos, 2003; Pennycook, 2007; Cutler, 2007; Terkourafi, 2010). According to the language focussed hip hop research vernacular, non-standard and hybrid linguistic practices are described as characteristic of this cultural genre (though see Stylianou, 2010), and within educational studies the creative and counter-hegemonic language use is considered a significant part of the pedagogical and political potentials of hip hop (Hill, 2009; Alim et al., 2009; Alim, 2011; Pennycook, 2007). Since online communication sites are by now common vehicles for self-expression, content sharing and engagement in both worldwide and local interest communities social media has, more recently, become an important field site for researching such popular cultural practices (Varis and Wang, 2011; Androutsopoulos, 2006, 2007, 2009).

In this article we report from a study of a group of adolescents in Copenhagen identifying as rappers and engaging in various rap events and mentoring initiatives. The functions and affordances of social media are significant for the construction of their local rap community. In fact, the creation of rap identities and the existence of the rap community partly depend on these communicative platforms. However, compared to previous studies of hip hop language, the development of the adolescents' rap videos on YouTube reveals the somewhat surprising observation that the young rappers increasingly use more monolingual, standard linguistic practices in their rap productions (Madsen and Karrebæk, in press; Madsen, in press). We argue that to fully understand this development, it is necessary to take into account the local, socio-cultural meanings given to particular linguistic resources and its relation to wider cultural models, and that this cannot be fully captured without attention to the ethnographic context and the sociolinguistic economy in which they are situated. By including these aspects

\footnotetext{
* Corresponding author. Tel.: +4524635394.

E-mail addresses: andst@hum.ku.dk (A. Stæhr), lianm@hum.ku.dk (L.M. Madsen).
} 
we demonstrate that the language use in the rap videos is partly related to the approach of the local rap mentors and the influence of hegemonic language ideological beliefs linking linguistic standard and correctness to intelligence. But the dominance of standard-linguistic practices in the rap productions is also related to audience considerations and ambitions of success as musician (see also Madsen, in press).

Research on CMC and social networking sites is often motivated by a primary interest in the social media as such. As a consequence of this many studies typically focus on a particular type of social media and investigate, for instance, general user behaviour (Miller, 2008; Larsen, 2009), the media's impact on social relationships (Livingstone, 2008; Ellison et al., 2007), its impact on peoples' engagement in popular culture (Leppänen and Häkkinen, 2012; Rymes, 2012) or the development of new communicative and linguistic genres within social media such as status updates on Facebook (Lee, 2011; Sørensen, 2012), weblogs (Miller and Shephard, 2004) or 'netnolect' (Li and Juffermans, 2011). Yet, any study of the social and linguistic life of contemporary youth can hardly overlook that a significant part of young people's everyday communication involves or takes place in social media, and this is our prime rationale for engaging with CMC. Studying CMC from this perspective entails, on the one hand, that social media is not examined as detached from other areas of everyday life and, on the other hand, that social media communication is included in our accounts of contemporary sociolinguistic processes in Copenhagen. In this way our work aims to contribute to current CMC research by carefully studying the contexts - also offline - for the local CMC activities, and it contributes to contemporary sociolinguistic research by including CMC as part of the sociolinguistic everyday life.

To achieve this we proceed with an introduction of our data, and we elaborate on how social media data can be approached from a linguistic ethnographic perspective. As a basis for discussing the language use in the rap productions in our case study in relation language in hip hop elsewhere, we continue with a brief review of the main findings of sociolinguistic and literacy pedagogical studies of hip hop. The wider sociolinguistic context of our field site is significant to understand the linguistic practices of the young rap musicians, and we describe this before we turn to the participants and the ethnographic context of the local rap community. These contextual accounts provide the foundation for our analysis of the adolescents' rap videos from YouTube, and we conclude with a discussion of the linguistic development we observe in the videos, in relation to our other ethnographic and linguistic data.

\section{Data and approach}

Our work is part of a collaborative project focused on adolescents and children from a culturally and linguistically diverse area of Copenhagen (Madsen et al., 2013). As part of our project we have carried out ethnographic field work in teams (Blackledge and Creese, 2010) in two secondary school classes during their final three years where the participants were on an average 13-15 years old. Our fieldwork covered most of the adolescents' everyday lives. We observed and participated in activities at school (in classes and during the breaks), leisure time activities, and some of the team members visited the adolescents in their homes (Ag and Jørgensen, 2013). Combined with this data collection we also carried out extensive online ethnography (Androutsopoulos, 2008, 2013). We collected rap videos made and uploaded by the adolescents on YouTube, recorded their interactions while they were engaged in internet searching and other CMC activities, and we created a Facebook profile called 'The language researchers' on behalf of the project. After informing the participants about our presence on Facebook we began to receive friend requests. We never took initiative to befriend the adolescents online, and the participants have given us explicit consent to use the data provided that all names are anonymized. In this article we focus on three boys, Isaam, Bashaar and Mahmoud, who formed a rap group, and we discuss different types of data covering their rap activities. These include their YouTube videos, interview data, field diaries and recorded interactions in the youth clubs they attended.

International hip hop scholars and critics usually treat rap music as a distinctive element within the wider frame of hip hop culture. Hill (2009, p. 33) describes how the youth he studies deploy the distinction between 'rap' and 'hip hop' as a distinction between 'real' (hip hop) and 'fake' (rap) representations of this popular culture. Yet, the participants in our study as well as their rap mentors exclusively use the term 'rap' to refer to their cultural practices. Therefore we use the term rap when we are concerned with the participants and the local rap environment, but when we relate to the international research we use the wider circulating term hip hop.

As a tool for daily communication, language and linguistic styles through repeated use come to be associated with particular people, places and purposes (Agha, 2007; Coupland, 2007). This makes language use a prime heuristic for tracing the experience and construction of personal and social identities, cultural interpretations, social differentation and alignments. Communication is often indirect and linked to activities and background understanding, and for research perspectives that overwhelmingly look to explicit claims and propositions for its evidence (e.g. in interviews and surveys), this is hard to capture. We seek to meet this challenge by approaching our study of social media and rap practices from the perspective of Linguistic Ethnography (Rampton et al., 2004; Blommaert, 2007), and a significant principle here is that the contexts for communication should be investigated rather than assumed. This approach sees social categories and structures as dependent on their (re)production in everyday life. It therefore focuses on lived local realities, and consequently investigates how these provide insight into larger-scale socio-cultural processes. The combination of an ethnographic focus on insiderknowledge, rich contextualization and participant reflexivity and the analytical refinement of linguistics is a particular strength. This allows us to analyze the details of communicative activities and their relation and sensitivity to the social contexts in which they are produced. Furthermore, consideration of the local, socio-cultural meanings given to particular semiotic resources and their relation to wider cultural models can be accounted for through the notion of indexicality (Ochs, 1992; Silverstein, 2003). Indexicality refers to the associations between forms and (typical) usage, contexts of use and 
stereotypes of users that are (re-)created in communicative encounters through linguistic and other signs. Indexical associations are metapragmatic because they characterise signs' links to pragmatically usable systems of signs, and metapragmatic activities on various levels. These levels range from widely circulating stereotypes to local speaker practices and contribute to enregisterment (Agha, 2003, 2007), that is the processes and practices whereby performable signs become recognized as belonging to distinct semiotic registers.

Social media communication, such as the sharing of rap videos, of course, involves metapragmatic activities. YouTube videos draw on already enregistered indexical associations through the use of linguistic and other signs, but in addition social media communication has the potential of contributing significantly to semiotic enregisterment because of its wide circulation. Hip hop culture is an example of globally widespread enregisterment of cultural forms - not the least linguistic, and in the section below we describe the language use associated with hip hop according to the international literature.

\section{Hip hop and language}

The language of hip hop has received scholarly interest from both a sociolinguistic (overview in Cutler, 2007) and a literacy pedagogical perspective (overview in Alim, 2011). Sociolinguistic studies of hip hop have been particularly interested in 1) the relationship between hip hop language and African American English (Morgan, 2002) and 2) the local appropriations of hip hop in various countries and regions outside the USA involving linguistic hybridity (Androutsopoulos and Scholz, 2003; Androutsopoulos, 2007, 2009). The linguistic style associated with hip hop has been described as closely related to AAE deploying, but also transforming, features of grammar and vocabulary rooted in AAE communicative practices (Cutler, 2007, p. 520). Furthermore sociolinguistic studies document how non-African Americans adopt linguistic practices associated with AAE as part of their hip hop involvement (Cutler, 1999; Bucholtz, 1999). Sociolinguistic studies of hip hop outside the USA characterizes the linguistic practices in localized versions of hip hop as establishing authenticity through the use of local linguistic resources combined with English hip hop terms (Alim et al., 2009; Pennycook, 2007; Cutler, 2007; Varis and Wang, 2011) and thereby appropriating linguistic features from its African American 'mother culture' (Androutsopoulos, 2009, p. 43). In Europe it appears a general feature of hip hop to use the entire linguistic repertoire of the local environment including nonstandard dialectal or sociolectal resources and, in contexts with large migrant communities, features of minority languages (Androutsopoulos and Scholz, 2003). The preference among Cypriot rappers studied by Stylianou (2010) for Standard Modern Greek proves an exception to this tendency. In her review of the sociolinguistic literature on hip hop Cutler notes that: 'Local dialects by virtue of their marginalized, stigmatized status fill a role similar to that of AAE in the USA' (Cutler, 2007, p. 525). The preference for non-standard language use in hip hop is related to the concern with establishing authenticity, which involves the idea of being true to ones roots as well as being streetwise. As Cutler explains:

Authenticity in hip-hop is a complicated construct that depends on many variables, but one component involves socioeconomic, ethnic and cultural proximity to the urban African American community where hip-hop is created and disseminated, that is 'the street' (Cutler, 2007, p. 529).

The hip hop pedagogical studies (Alim, 2011; Alim et al., 2009; Hill, 2009; Pennycook, 2007) pay particular attention to the critical language awareness involved in creating rap lyrics. Hip hop is considered a cultural form with great potential for expressing political ideas, identity affiliations and engaging with societal issues, and crucial parts of these expressions are of course linguistic. Furthermore, hip hop as cultural genre is viewed as a vehicle for expanding traditional views of language by allowing for creative linguistic practice, such as mixing, innovative slang etc. (Alim, 2011; Alim et al., 2009). Alim refer to the language and educational ideology of hip hop as ill-literacy using a term that plays on public discourses' evaluation of hip hop culture as 'illiterate', but invert this notion by emphasising the meaning of 'ill' in hip hop culture, where it is used to positively evaluate skilled and counter-hegemonic practices. As Alim explains:

This Hip Hop-centered language and educational ideology is made explicit by Jubwa of Soul Plantation (a Hip Hop emcee and deejay from East Palo Alto, California), who refers to "standard English" as limited and Black Language as limitless (Alim, 2011, p. 121, emphasis in original).

The language pedagogical qualities of hip hop culture rests on the reframing of notions of correctness by linking them to hip hop cultural priorities rather than institutionally sanctioned norms of grammar rules etc., and it emphasizes the artistic creativity involved in the verbal productions indexing 'youth's attempts to negotiate their ever-changing, unstable, and fluid realities' (Alim, 2011, p. 123). Popular culture in general is considered a space for youth to negotiate identity and belonging within a frame of peer culture (Ito et al., 2010, p.9).

Pedagogical and educational aspects of hip hop are certainly significant to the engagement with rap music among the adolescents in our study, but as we will show, the verbal productions of the young rappers contrast with the tendencies of non-standard and hybrid language use described in sociolinguistic studies of hip hop. Furthermore, the language ideologies of the local rap community in the context of our research differ strikingly from the ill-literacy perspective.

\section{Sociolinguistic context}

Before we turn to the specific ethnographic context and our data, however, some contextual information on the sociolinguistics of Danish as well as the sociolinguistic awareness of the participants should provide a useful entry point for our 
discussion of their language use in rap activities. Briefly described, the overall sociolinguistic development in Denmark is characterized by strong linguistic homogenization and a dominating standard ideology (Kristiansen and Jørgensen, 2003; Pedersen, 2009). Kristiansen (2009, p. 168) suggests that Danish today is possibly more homogeneous than any other language with millions of speakers. Currently, there is very little grammatical variation within speech observed around the country. Local 'accents' are signified primarily by prosodic colouring, and the existing nationwide variation in segmental phonetics is strongly dominated by developments and spread from Copenhagen speech (Kristensen, 2003; Kristiansen, 2009). However, as recent studies of online and offline interaction, language attitudes, and language ideologies show (Stæhr, 2014a; Madsen, 2013; Jørgensen, 2010; Møller, 2009; Maegaard, 2007), this does not mean that young speakers in the Copenhagen area grow up without ideas about linguistic differences and their related social values. The dialectal and the traditional sociolectal differences might be close to extinct judging by the number of varying linguistic features, but only a few linguistic signs are necessary to bring out the wider social connotations of particular ways of speaking. Subtle features like prosodic colouring can still have the strong effects of signalling, for instance, a rural or an urban persona.

Our study of explicit metalinguistic accounts from our participants hints at a sociolinguistic transformation taking place among contemporary youth (Madsen et al., 2010; Madsen, 2013; Møller and Jørgensen, 2013). During interviews with the participants in our study in the first year of our collection period they introduced labels for two ways of speaking that differ from what they refer to as 'normal'. One was 'integreret' (integrated) and the other was referred to with varying labels: predominantly 'gadesprog' (street language), but also 'perkersprog' (equivalent to paki language) or 'slang' (slang). 'Perker' is originally a derogatory term used about immigrants - equivalent to 'paki' or 'nigger'. In in-group use, however, the term refers to a social category defined by ethnic minority status (in relation to the Danish majority society) across various ethnicities. Moreover, in local in-group use 'perker' also invokes values of toughness and street-credibility (Madsen, 2013). In spite of the different naming practices, there was general agreement in the reports on characteristic features of this way of speaking. Characteristic features of 'street language', according to the participants, include slang, swearing, affricated and palatalised tpronunciation, poly-lingual mixing practices, what they refer to as a 'strange accent' and linguistic creativity (linguistic innovations). This way of speaking is associated with the stereotypic indexical values of toughness, masculinity, youth, panethnic minority street culture and academic non-prestige. In contrast, the participants characterise 'integrated' speech by features of distinct pronunciation, abstract and academic vocabulary, high pitch, quiet and calm attitude and ritual politeness phrases. This way of speaking is associated with up-scale culture, sophistication, authority, emotional control and aversion to rudeness, academic skills, politeness and respect. Thus, in the values and privileges it evokes, 'integrated' seems to be undergoing enregisterment as a conservative standard code, and 'street-language' is enregistered partly in opposition to this (see detailed analysis in Madsen, 2013). Yet, the label for the more conservative speech style of 'integrated' (in Danish public predominantly used about satisfactorily adapted immigrants) as well as its oppositional relation to the contemporary urban vernacular speech (containing features indexing cultural and linguistic diversity) also bring about a dimension of minority/ majority relations that has not previously been included in the stereotypical associations related to a conservative standard register. In addition, the socio-hierarchical dimension of contemporary youth speech has not until recently received attention in Danish sociolinguistics.

Of course, there can be significant differences between speakers' reports about language use and their actual linguistic practice. The accounts summarised here provide important insights into the speakers' ideas about linguistic stereotypes, but the study of how linguistic stereotypes are brought into use for situated pragmatic functions in particular communicative acts may add to and possibly alter the picture (Rampton, 2006; Jaspers, 2011 are good examples of this). In our discussion of the rap-oriented activities we shall see how the situated linguistic practices of the adolescents relate to these sociolinguistic tendencies, and we shall open this discussion with a description of the participants' engagement in the local rap environment.

\section{The participants' involvement in the local rap environment}

Isaam, Bashaar and Mahmoud have been friends since they were very young. They grew up in the same neighbourhood in Copenhagen and attended the same school (Mahmoud and Isaam in the same class and Bashaar in the parallel class). During our fieldwork they hung out together every day at school during the breaks, and several times during the week they attended the local youth club. Bashaar was born in Iraq and immigrated to Denmark with his family when he was two years old. Mahmoud and Isaam were born in Denmark, Mahmoud has Moroccan family background and Isaam has Palestinian and Lebanese background.

Isaam told us how they got inspired by watching a movie about a boy from the ghetto becoming a successful rap artist and therefore began to make their own rap music, and during our field work they were heavily engaged in a rap-band, here called Mini G's. They signalled affiliation with rap culture through the way they dressed, the music they listened to, the YouTube videos they watched, and through their composing of own music and lyrics, a topic they often discussed in school breaks and in the youth club. The boys listened to a broad spectrum of both Danish and international artist within different rap genres. Their rap activities were highly visible in the classroom when we began our research. For instance, they wore T-shirts with their group name, and articles from local newspapers about their performances were hung on the wall of the classroom (See Fig. 1).

The Mini G's practised their rap music predominantly in connection with activities in and around two youth clubs. One was the local club in the neighbourhood close to the school at Amager where we conducted our research (we refer to this as 'the local youth club'). The other was a youth club in a suburb to Copenhagen (we refer to this as 'the suburban youth club'). 

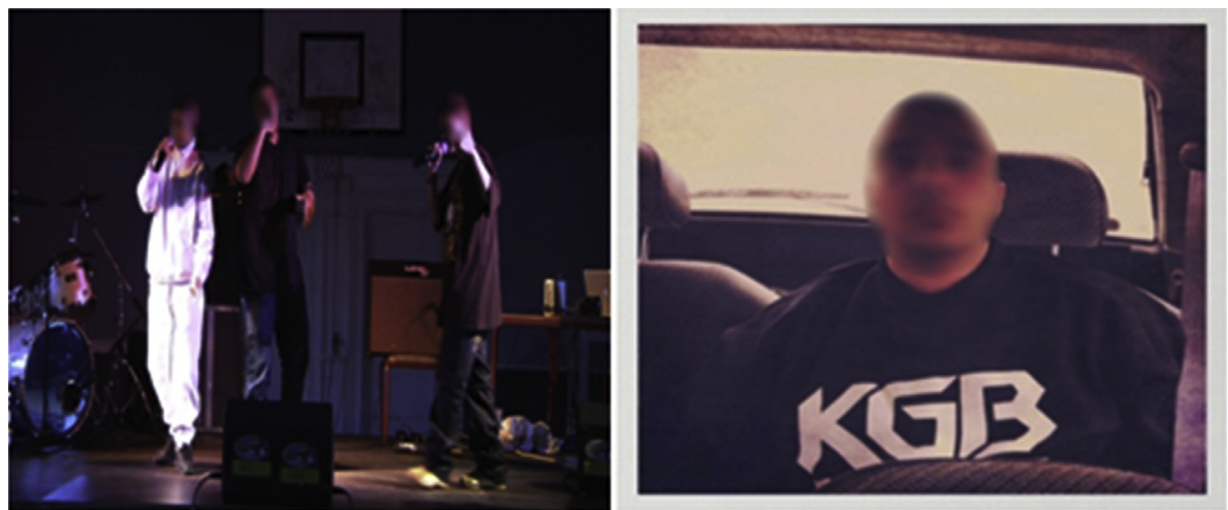

Fig. 1. Left: The Mini G's perform at a rap-contest in the youth club. Right: Bashaar sitting in the car on his way to a concert wearing a T-shirt advertising the 'musical commune' KGB.

Through the local youth club the boys came into contact with a rap mentor who voluntarily taught and produced rap music with local adolescents. The boys refer to him as their 'manager' (see excerpt 3). He was a leading figure in the organisation Ghetto Gourmet, which had a so-called rap academy (workshops led by the rap mentors for youth interested in practising rap music) as one of its activities. This organisation also offered workshops to Copenhagen schools, and the boys' two school classes participated with their Danish teachers in one of these as an alternative way of learning about poetry (in the 8th grade, October 2009, see Madsen and Karrebæk, in press). Through the involvement in Ghetto Gourmet the boys participated in a concert were they met the rapper, Ali Sufi. He was later involved in teaching rap at the suburban youth club, and because Bashaar had a family contact who worked at the club, they also began to attend the club regularly and work with him there. Sufi initiated another rap association that Issam and Bashaar were members of, the KGB (meaning: 'Kaster Guld Barrer', 'Throws Gold Bars'). This organisation was presented (in an introduction video on YouTube) as a 'musical commune'. Both communities overlapped in participants and activities and they provided the main framework of activities for the boys rap interests. Through these they participated in local concerts and national rap competitions as well as the regular meetings in the youth clubs.

It was characteristic of both rap associations that they drew heavily on the infrastructures provided by digital social media. Both Ghetto Gourmet and KGB, for instance, had Facebook pages and presentation videos on YouTube, and another initiative by Sufi was a dedicated digital rap channel, RapMoves TV, and a digital production company (See Fig. 2).

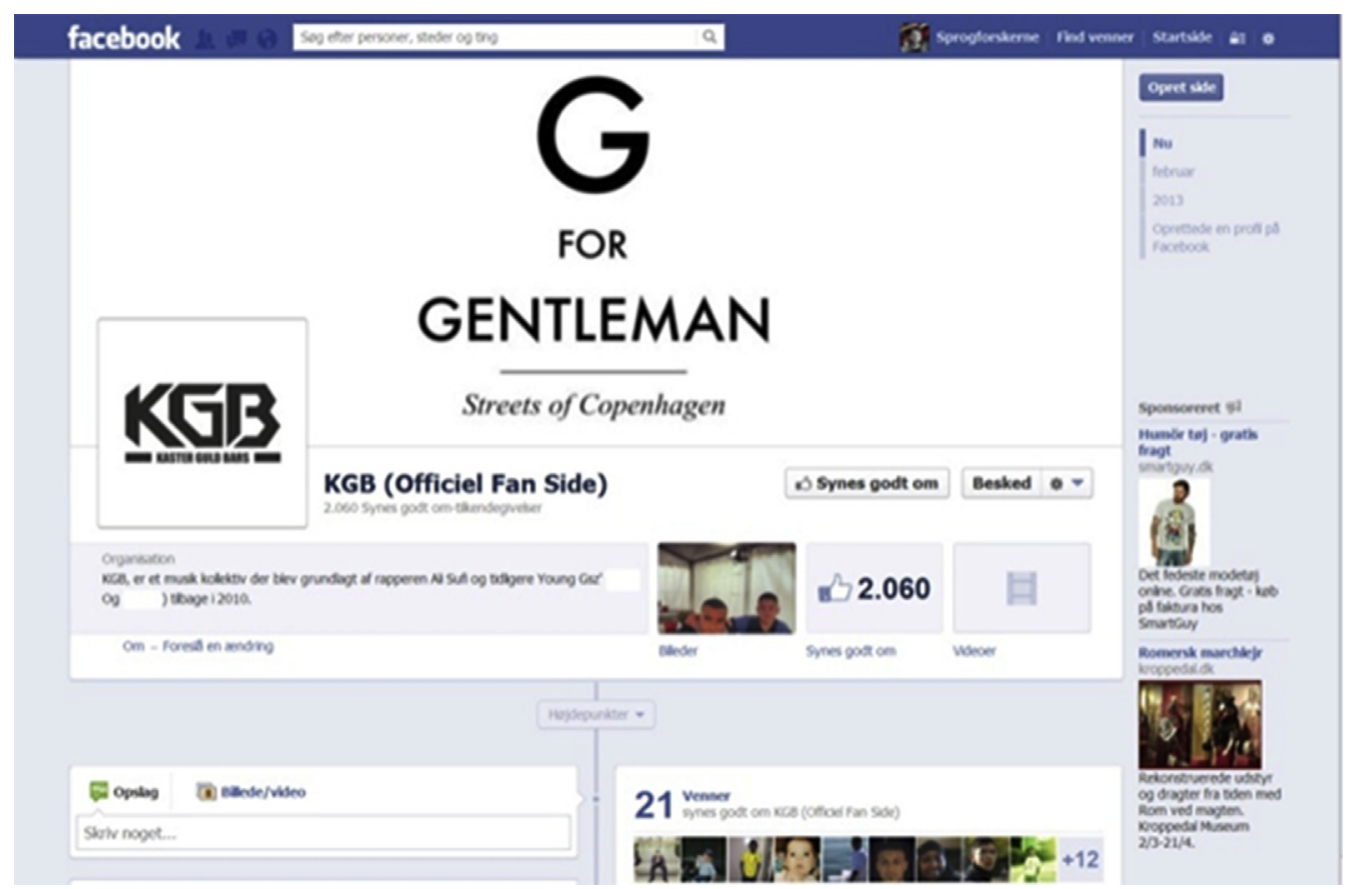

Fig. 2. The KGB Facebook page. 
YouTube and Facebook also play an important role for how the boys connected with the communities and expressed themselves as rappers. On Facebook they engaged in various rap related activities from posting pictures from concerts to sharing and recommending each others' music videos. Following with the spread of smart phones and the increased popularity of Facebook the boys to a greater extent began to share their music with each other and brand themselves as rappers through online channels. So in this respect a significant part of practicing a rap identity depended on social media activities. Engaging in practices such as posting songs on YouTube, taking part in web-based communities, and interacting with fans through Facebook were central to identifying as a rapper in this context, and we will now look further into the boys' rap productions.

\section{Rap productions on YouTube}

During our fieldwork we collected 8 rap videos that had at some point been shared on YouTube (with permissions from the participants). Table 1 provides an overview of the rap songs with information about the year they were shared, the main content and general observations regarding the linguistic style of the lyrics.

The overview of the rap productions illustrates a noticeable change between the two rap songs from 2008 and the productions from 2009 when the boys became involved with Ghetto Gourmet. What is striking about the change of rap style in these productions is that it illustrates a shift from what the participants themselves describe as 'gangster rappers' to 'serious rappers' (Stæhr, 2010; Madsen, in press). This seems to involve a change in linguistic style as well, and we will treat this in more detail by comparing the two songs 'Wannabe' and 'Just a rapper'. In the early songs the adolescents express affiliation with the local street gang, violence in the neighbourhood and opposition to the police. In the song 'Wannabe', wannabe G's (G for 'gangster') are presented as worthless compared to the song protagonists. The boys 'dis' wannabes, claim authority and local street credibility. Furthermore, the song is framed as a gangster rap as the video is initiated with the sound of a shootout, and the boys index toughness through their bodily appearances on the shifting still pictures which their video consist of (see Fig. 3). Note for example how Bashaar in Fig. 3 'throw' a West Coast hand sign to the camera and thereby signals affiliation with a particular strand of hip hop originating from the Western part of the USA. This signal of affiliation makes sense because Bashaar (as he reports in an interview) is a huge fan of the American West Coast rapper '2pac' (Tupac Shakur).

Table 1

Overview of rap productions.

\begin{tabular}{|c|c|c|c|}
\hline $\begin{array}{l}\text { Title and year } \\
\text { (Our translation) }\end{array}$ & Main topics of content & Linguistic style of lyrics & Group name and affiliation \\
\hline $\begin{array}{l}\text { 'Where we come from' } \\
\text { YouTube video, } 2008\end{array}$ & $\begin{array}{l}\text { The local street gang } \\
\text { Affiliation with violence and crime in } \\
\text { the local neighbourhood } \\
\text { Identifying as 'Pakis' - contrasted to } \\
\text { nationalist right wing politics } \\
\text { Opposition to police }\end{array}$ & $\begin{array}{l}\text { Predominantly monolingual Danish } \\
\text { with a few slang and swear words, } \\
\text { English expressions and features of } \\
\text { minority languages }\end{array}$ & Mini G's \\
\hline $\begin{array}{l}\text { 'Wannabe' } \\
\text { YouTube video, } 2008\end{array}$ & $\begin{array}{l}\text { The local street gang } \\
\text { Worthless wannabes - contrasted to } \\
\text { real 'G's } \\
\text { Multicultural youth - } \\
\text { contrasted to nationalist right wing } \\
\text { politics }\end{array}$ & $\begin{array}{l}\text { More hybrid linguistic style with } \\
\text { incorporation of English and vocabulary } \\
\text { from minority languages } \\
\text { - explicit meta-linguistic comments and } \\
\text { demonstration of mixing }\end{array}$ & Mini G's \\
\hline 'Just a rapper’ & Meta-rap & Predominantly monolingual (standard) & Mini G's/Ghetto Gourmet \\
\hline YouTube video, 2009 & $\begin{array}{l}\text { Competent rappers } \\
\text { 'Anti-gangster' }\end{array}$ & $\begin{array}{l}\text { Danish with vocabulary indexing up- } \\
\text { scale culture }\end{array}$ & (Ali Sufi) \\
\hline $\begin{array}{l}\text { ‘Obama’ } \\
\text { YouTube video, } 2009\end{array}$ & $\begin{array}{l}\text { Addressing US president about } \\
\text { problems ranging from crime in local } \\
\text { neighbourhood to poverty in Palestine, } \\
\text { Guantanamo, and climate problems }\end{array}$ & $\begin{array}{l}\text { Predominantly monolingual (standard) } \\
\text { Danish with a few English and slang } \\
\text { expressions }\end{array}$ & Mini G's/Ghetto Gourmet \\
\hline $\begin{array}{l}\text { 'It's how we do it' } \\
\text { YouTube video, } 2009\end{array}$ & $\begin{array}{l}\text { Meta-rap about qualities of community } \\
\text { of Ghetto Gourmet and their music }\end{array}$ & $\begin{array}{l}\text { Predominantly monolingual (standard) } \\
\text { Danish with a few English and slang } \\
\text { expressions }\end{array}$ & Mini G's/Ghetto Gourmet \\
\hline $\begin{array}{l}\text { 'The problem solver' } \\
\text { YouTube video, } 2009\end{array}$ & $\begin{array}{l}\text { Love rap with 'anti-gangster' aspects: } \\
\text { 'you're not my bitch you're my life saver' }\end{array}$ & $\begin{array}{l}\text { Predominantly monolingual (standard) } \\
\text { Danish with a few English and slang } \\
\text { expressions }\end{array}$ & KGB/RapMoves (Ali Sufi) \\
\hline $\begin{array}{l}\text { 'New side' } \\
\text { YouTube video, } 2010\end{array}$ & $\begin{array}{l}\text { Meta-rap about qualities of community } \\
\text { of KGB and their music }\end{array}$ & $\begin{array}{l}\text { Predominantly monolingual (standard) } \\
\text { Danish with a few English and slang } \\
\text { expressions }\end{array}$ & KGB/RapMoves (Ali Sufi) \\
\hline $\begin{array}{l}\text { 'Move steps' } \\
\text { YouTube video of live } \\
\text { performance from } \\
\text { release concert of } \\
\text { Ghetto Gourmet, } 2011\end{array}$ & $\begin{array}{l}\text { Meta-rap about being competent city } \\
\text { rappers seeking to improve }\end{array}$ & $\begin{array}{l}\text { Predominantly monolingual (standard) } \\
\text { Danish with a few English and slang } \\
\text { expressions }\end{array}$ & Mini G's/Ghetto Gourmet \\
\hline
\end{tabular}




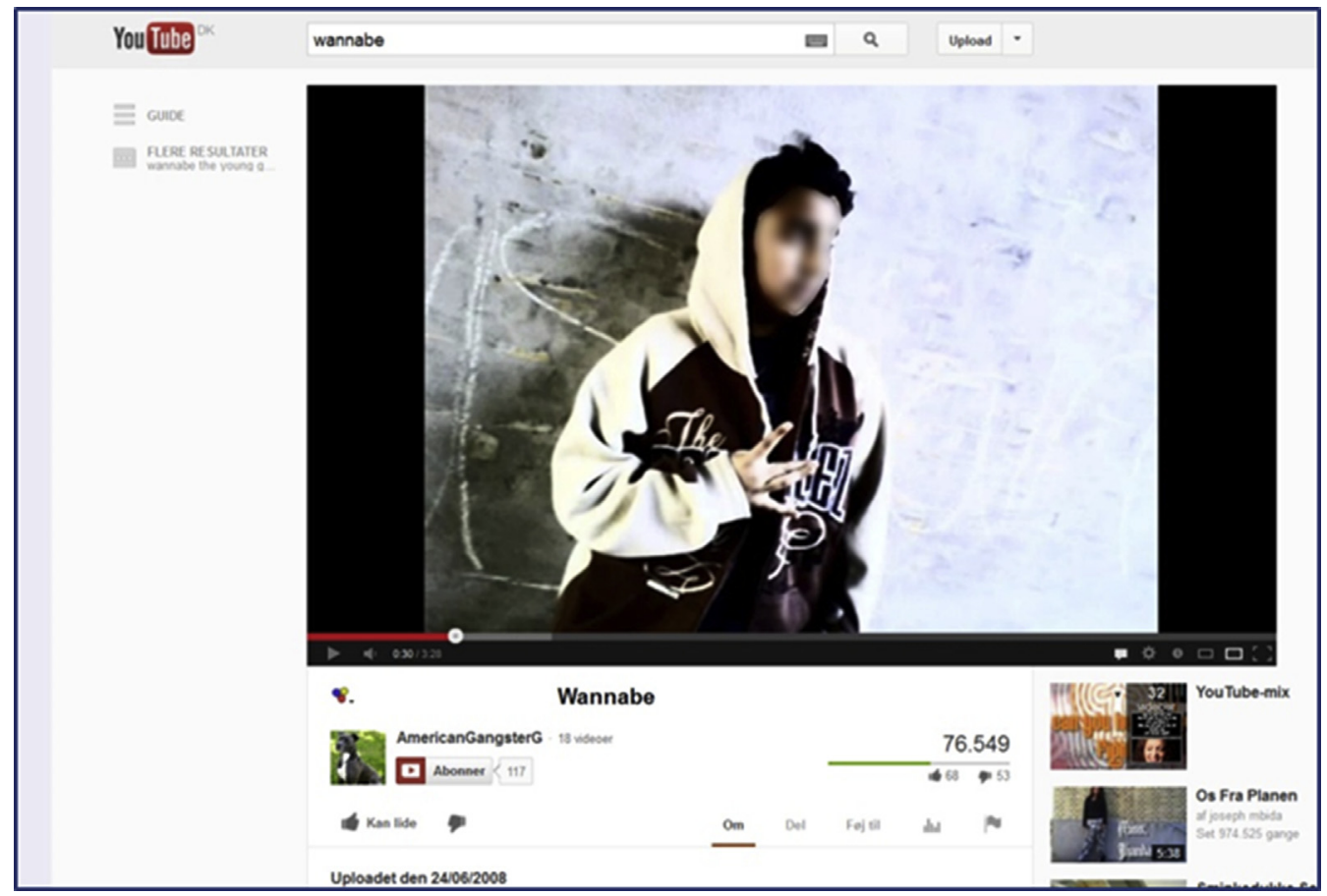

Fig. 3. YouTube video 'Wannabe'

Furthermore, many of the comments to the video draw on similar tough masculine associations as for example: 'your mother looks like a fagot I fuck you your little piece of shit'. Their tough appearance in the song on the level on content correlates with their verbal, linguistic performance as it highlights the linguistic diversity associated with the street language:

Excerpt 1: Transcription of lyrics from 'Wannabe', 2008. Features associated with 'street language' originating from Arabic or Kurdish in bold, features associated with English in italics.

\begin{tabular}{ll}
\hline Original & Translation \\
Eow yeah wannabes & Eow yeah wannabes \\
de kan ikke blive som Mini G's & you can't be like the Mini G's \\
(Exkaran) han er alt for klam & (Exkaran) he is way too gross \\
eow I' nogle tabere & eow you're looser \\
I efteraber & you copy \\
I kalder jer selv for en $G$ & you call yourself a $G$ \\
do you wannabe? & do you wannabe? \\
I har intet værdi & you have no value \\
do jeg er ikke Dansk Folkeparti & do I'm not 'Danish People's Party' \\
så prøv at hør' & so try to listen \\
det 'os der før' & we are in front \\
for det 'her på Amar' vi taler vores sprog & 'cause it's here in Amar' we speak our language \\
acra para vur abow & acra para vur abow \\
\hline
\end{tabular}

The linguistic style of the song is equivalent to the everyday peer style of the adolescents and illustrates the poly-lingual character of their speech (Jørgensen, 2008; Jørgensen et al., 2011) by including features that can be associated with Danish, English, Kurdish and Arabic (see also Madsen and Karrebæk, in press). For example, they use the word 'eow' which is often used among the adolescents to attract somebody's attention, and they list the words 'acra' ('police'), 'para' ('money'), 'vur' ('fist fight') and 'abow' (a kind of exclamation) as belonging to their language on Amager. In this way the lyrics contain explicit meta-linguistic commentary, as the text addresses local hybrid speech practices and demonstrates what is referred to as 'our language '. Finally, the rap text involves a political dimension through the positioning as 'not Danish People's Party' - a right wing nationalist party, and it links the hybrid speech style to not affiliating with this nationalist party. Furthermore, the stereotypical tough masculine values associated with street language (Madsen, 2013) here correlates with their confrontational appearance in the lyrics (the 'dissing' of wannabes) and the gangster rap frame of the video.

In what the adolescents call their more 'serious' rap the style is very different. Similarly to the 'Wannabe' video, the visual side of this production consist of shifting still pictures. The boys' expressions on these pictures are, however, different. They appear in light colours and as we see in Fig. 4 and deploy hand postures associated with Buddhist greetings in contrast to the West Coast hand sign in Fig. 3. 


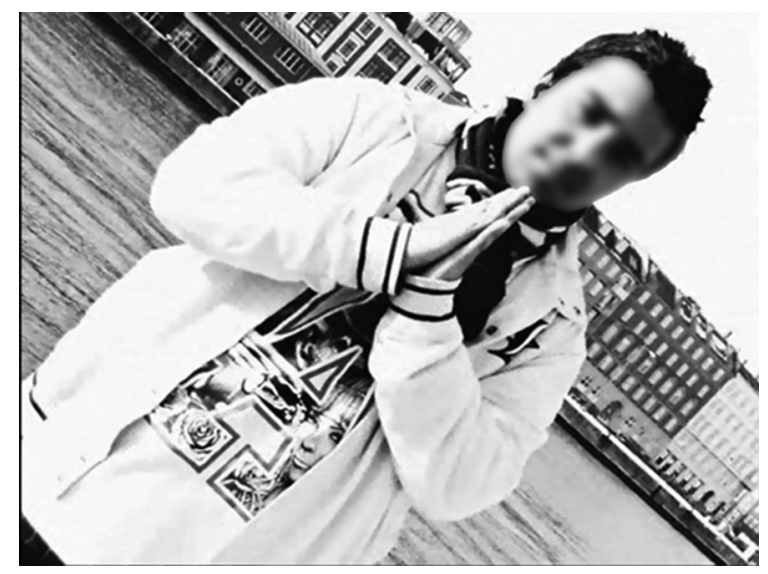

Fig. 4. Still picture from YouTube video 'Just a rapper'.

The message of this song is to be a competent rapper, to be yourself (also emphasized by the title) and not an aggressive gangster.

Excerpt 2: Transcription of rap lyrics from 'Just a rapper', 2009. Grammatical change in number underlined. Focal parts emphasized in bold.

\begin{tabular}{ll}
\hline Vi er her & We are here \\
vi er mini ghetto gourmeter & we are mini ghetto gourmets \\
lad mig lige prøve at argumentere & just let me try to argue \\
jeg er bare en rapper du må acceptere & $\begin{array}{l}\text { I'm just a rapper you have to accept } \\
\text { the things I deliver } \\
\text { de ting jeg leverer }\end{array}$ \\
plus mine rim de eksploderer & plus my rhymes they explode \\
jeg er bare en rapper der rapper om mit liv & I'm just a rapper who raps about his life \\
gider ikke spille smart og være aggressiv & don't want to play smart and be aggressive \\
jeg er bare mig selv og ikke andet & I'm just me and nothing else \\
mine rim de er ikke for fin & my rhymes they're not to posh \\
den er ikke for vandet & it's not too vague \\
\hline den er ren den er flot den er venlig & it's clean it's nice it's friendly \\
mine raptekster er helt uimodståelige & my rap lyrics are completely irresistible \\
Omkvæd: & Chorus: \\
I ved jo godt hvem vi er & Well you know who we are \\
står på scenen og vi tør & on the stage and we dare \\
poesi og harmoni & poetry and harmony \\
gangsterrap lad mig være fri & gangster rap spare me \\
\hline
\end{tabular}

The linguistic style of the lyrics is predominantly monolingual standard Danish (apart from a shift in grammatical number, underlined), and it includes a range of expressions associated with more upscale cultural norms, such as 'argumentere' (argue), 'acceptere' (accept). It can be characterized as a meta-rap and describes the rappers lyrics as 'venlig' (friendly) and 'uimodståelig' (irresistible). The chorus emphasizes poetry and harmony and explicitly dis-aligns with gangster rap. This message is supported by the rather old-fashioned and high style expression 'Lad mig være fri' (spare me). 'Just a rapper' was created during the boys' participation in Ghetto Gourmet (and refers to this as well 'we are mini Ghetto Gourmets') and in their so called rap academy. This academy claimed in a web text to bring education 'from the ivory tower back to the streets' (see details in Madsen and Karrebæk, in press). However, it is safe to say that this rap production does not draw on stereotypical streetwise indexes.

The boys' musical productions after 2009 (created during the involvement with the local rap mentors), continues to be concerned with positioning as competent rappers, but some also focus on societal problems and political issues. For instance, the 'Obama' song (made as a part of 'rap politics') addresses political problems on a local as well as a global scale and it includes the explicit statement 'I'm a political rapper, but I'm not a diva' ('Obama' 2009, our translation). Both in content and style there is less emphasis on ethnic minority identity aspects and the cultural diversity of the young rappers everyday life in the later songs. From identifying as 'paki' (perker) and employing a local, linguistically hybrid vernacular speech style the productions made within the Ghetto Gourmet and KGB communities are characterised by being more standard and monolingual. It is important to add that the boys' pronunciation of the lyrics in their performance is not always standard Danish, but it is closer to a standard pronunciation in the rap performances than in their everyday speech. On the level of vocabulary their linguistic style in the later rap songs is indeed, as we have seen in excerpt 2, more standard, and at times with clear academic and up-scale cultural connotations. In the meta-linguistic reflections described in Section 4, the participants specifically point to such vocabulary as a prime feature of the speech style they refer to as 'integrated' - a speech style associated with teachers and adults, respect, academic skills and up-scale culture (e.g. Madsen, 2013; Møller and Jørgensen, 2013). In this linguistic sense the young rappers seem to become more integrated in their linguistic style through their rap trajectories. 
In sum, based on the development of the young rappers as it is reflected in their YouTube videos, we see that their involvement with the rap-political workshops and the mentors seems to results in:

- A disaffiliation with gangster-rap and its associated values

- A certain political engagement (with problems of inequality and crime) expressed in their lyrics

- Identity positioning as part of particularly competent urban rap communities and a central concern with meta-rap

- Less use of non-standard and mixed youth vernacular linguistic practices and more use of a standard, academic style (corresponding to their own descriptions of 'integrated' speech)

What is surprising, compared to the international sociolinguistic and pedagogical literature on hip hop, is that linguistic indexes of local youth culture (and the hybridity it involves) are hardly ever used in their rap music after their engagement with the mentors. Judging by their artistic expressions one could be tempted to say they are linguistically mainstreamed rather than emancipated, but to explain this it is necessary to attend to our ethnographic data and to the boys' everyday practices related to their rap-activities.

\section{Rap, education and language}

Andreas talked to the boys about the difference between the rap productions they have posted on YouTube in 2008 and 2009, and the young rappers present the understanding that their rap music involvement has had an impact on their attitude to school:

Excerpt 3: 'Rap saved us'

Group-interview with Andreas, May 2009. Participants: Mahmoud (Mah); Bashaar (Bas); Isaam (Isa); and researcher, Andreas (And), My translation. Focal parts emphasized in bold.

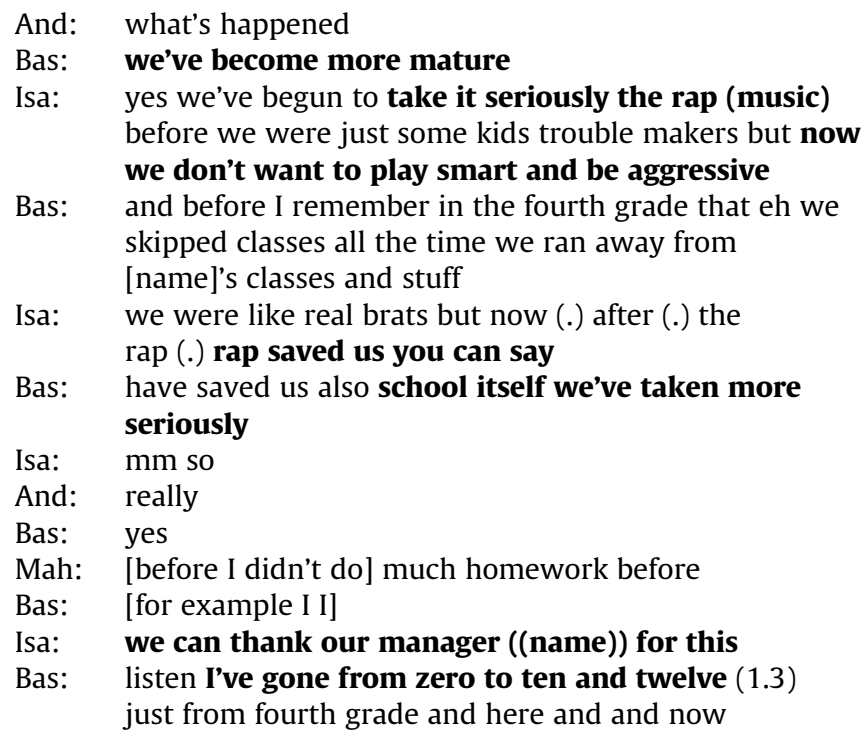

The most significant point to make from the participants' expressed understandings in the interview here is that the development towards maturity and seriousness in relation to rap music is presented as closely related to improvement of school performance (line 11 and 19). The boys claim that they have been 'saved by rap' and even express thanks to their manager. This act involves indexical association with the genre of a 'thank you speech' within the field of music and arts. So they are not only presenting themselves as good students, but also as rap artists. In this construction they draw on an understanding of the rap-activities and mentor-relationships as important for their educational development (see also Stæhr, 2010; Madsen and Karrebæk, in press; Madsen, in press).

In excerpt 4, however, a different understanding of the relationship between rap music and school is expressed by a friend in the local youth club. The excerpt illustrates part of their rap-related activities in club. Mahmoud and Bashaar are writing a climate rap, which is also homework for school, but the activity takes place in the leisure context in which they often worked on their music. This makes the setting for the activity somewhat hybrid and the linguistic practices they employ during this sequence relates to similar hybrid relationships between peer and school cultural resources. The boys jointly create the lyrics for the song, and Mahmoud writes them down. Before this sequence the writing has led Bashaar to make fun of and correct Mahmoud's spelling of the word 'temperature' (see Madsen, 2011; Stæhr, 2010, chapter 6). So the school-oriented frame and a norm of correctness have indeed been made relevant. A third participant joins the conversation at the beginning of excerpt 2 , Madiha, a girl, who is also a regular to the youth club. 
Excerpt 4: 'Do your homework'

Recording from the youth club, October 2009. Participants: Bashaar (Bas); Mahmoud (Mah) and Madiha (Mad). Rap marked in Italics.

\begin{tabular}{|c|c|c|c|}
\hline & & Original & Translation \\
\hline 1 & Mah : & [den stiger] ((rapper)) & [it rises] ((rapping) \\
\hline 2 & Mad: & [Koran xxx kom nu] lav & [Koran xxx come on] do your \\
\hline 3 & & jeres lektier få jer en & homework get yourself an \\
\hline 4 & & uddannelse (.) & education (.) $\downarrow$ rap Koran do \\
\hline 5 & & $\downarrow$ rap Koran tror I I får & you think you'll get \\
\hline 6 & & penge [for det] & money [for it] \\
\hline 7 & Bas: & [HVOR MEGET] HVAD & {$[\mathrm{HOW}$ MUCH] WHAT } \\
\hline 8 & & HVAD TROR DU JEG FIK I & WHAT DO YOU THINK I GOT IN \\
\hline 9 & & FRANSK I DAG (.) $\underline{\text { TI }}$ & FRENCH TODAY (.) TEN \\
\hline 10 & & HISTORIE FIK JEG TOLV & HISTORY I GOT TWELVE \\
\hline 11 & & MATEMATIK FIK JEG TI & MATH I GOT TEN \\
\hline 12 & & LAD VÆRE MED AT SNAKKE & $\mathrm{DON}^{\prime} \mathrm{T}$ TALK \\
\hline 13 & & WALLAH & WALLAH \\
\hline 14 & & $(2.0)$ & $(2.0)$ \\
\hline 15 & Mad: & (ej hvor skulle jeg vide & (well how would \\
\hline 16 & & $\operatorname{det}$ fra) & I know) \\
\hline 17 & Mah: & [temperaturen (.) den & [the temperature (.) it's \\
\hline 18 & & stiger] & rising] \\
\hline 19 & & $(($ rapper $))$ & $(($ rapping $))$ \\
\hline 20 & Mad: & [øh JA I FORHOLD TIL ANDRE] & [eh YES COMPARED TO OTHERS] \\
\hline 21 & & HVAD FIK DU MOUD & WHAT DID YOU GET MOUD \\
\hline 22 & Bas : & Mahmoud fik sgu også ti & Mahmoud also got bloody ten \\
\hline 23 & Mah: & TI I FYSIK OG & TEN IN PHYSICS AND \\
\hline 24 & & $\mathrm{KE} \uparrow \mathrm{MI} \quad(0.3) \quad \underline{\mathrm{TOLV}} \mathrm{I}$ & CEMIS TRY (0.3) TWELVE IN \\
\hline 25 & & $\mathrm{BIOLO} \uparrow \mathrm{GI}$ & BIOLO $\uparrow$ GY \\
\hline
\end{tabular}

$(($ wallah, Arabic origin $=$ I swear $))$

Madiha interrupts Mahmoud's rap with the suggestion that the boys do homework instead of rap music in order to get an education (lines 1-6). Thereby she seems to articulate an assumption that rap does not lead to income (as education does) or she, perhaps, implies that the boys' rap music is not at a level that will lead to economic success. So Madiha constructs a contradiction between the youth cultural practices such a rap music and general measures of societal success, at least in relation to Mahmoud and Bashaar. However, to do so, she employs non-standard linguistic features characteristic of the 'streetlanguage'. The linguistic features include a particular prosodic pattern and the slang expression Koran used as intensifier (line 2 and 5) and index peer culture and streetwise values rather than educational skills (e.g. Madsen, 2013). Bashaar does not argue against the expressed assumption, nor does he claim that they are in fact engaged in doing homework. Instead he defensively and loudly asks Madiha a rhetorical question about his marks and continues by listing a range of the high marks he has recently received in school as an answer (line 7-13). This seems to function as a demonstration of his academic capabilities, and a way of positioning himself as school-skilled (in line with his earlier spelling corrections). Still, similar to Madiha, he deploys linguistic features associated with the vernacular speech style. These are both prosodic and lexical (e.g. the expression wallah, line 12). 
Finally, Mahmoud, too, lists high marks in several subjects using the same intonation (lines 23-25). Excerpt 2 thereby illustrates how the boys defend their school competence as a reaction to the articulation of an assumption of an opposition or at least lack of connection between rap-culture and school success. The example shows that the close relation between school competence and hip hop activities expressed by the boys is not uncontested - in this case it has to be defended. But like above the boys manage a simultaneous positioning as both good students and rap artists, and this example is typical of how these boys in many ways successfully, blend dominating educational norms and positive school orientation with peer and popular cultural norms and semiotic activities such as linguistic vernacular forms and rap (Madsen, 2011; Madsen and Karrebæk, in press; Stæhr, 2014a). The example shows that in their peer-interactions around rap non-standard vernacular speech practices are used, even when the interaction involves a strong orientation to school achievements.

In the next excerpt we shall see an example from a recording in the studio in the suburban youth club with their rap mentor. It illustrates the recording work, interaction around the recording and the mentor's effort to film the recording (to use it for online productions). Just before this excerpt Isaam has had a failed attempt at performing his part of their song:

Excerpt 5: 'Inspiration'

Self-recording by Bashaar in suburban youth club, March 2011. Participants Bashaar (Bas); Isaam (Isa); another rap group member, Salim (Sal); rap mentor (Men). Rap in italics.

\section{Original}

Bas : åh du laver $\uparrow$ sjov det er

1

2

3

4

5

6

7

8

9

10

14

15

16

18

19

20

21

22

23

24

25

26 $\uparrow$ ikke sjovt jeg vil gerne

INSPIRERES af dig

Isa : så kom 个tættere på (.) xxx

jeg skal stå xxx

Bas : så kom RAP $\uparrow D E R$ så skru ned mand (.) $\downarrow$ kom

Isa : inspiration kald det hustle eller flow

se vi ender ikke $i$ fængsel

for vi hustler vores

flow forstår du

velkommen til dyreparken

2300 hvor vi shh

((hiver efter vejret))

$>$ jeg kan ikke få luft

sig 2300 for mig <

Bas : ok [kom]

Men: [må] jeg ikke lige filme

Isa: nej mand

Men: jo

Isa: nej

Men: jo:

Bas : [hvor]

Isa : [ikke] nu Koran jeg sveder

som et dyr

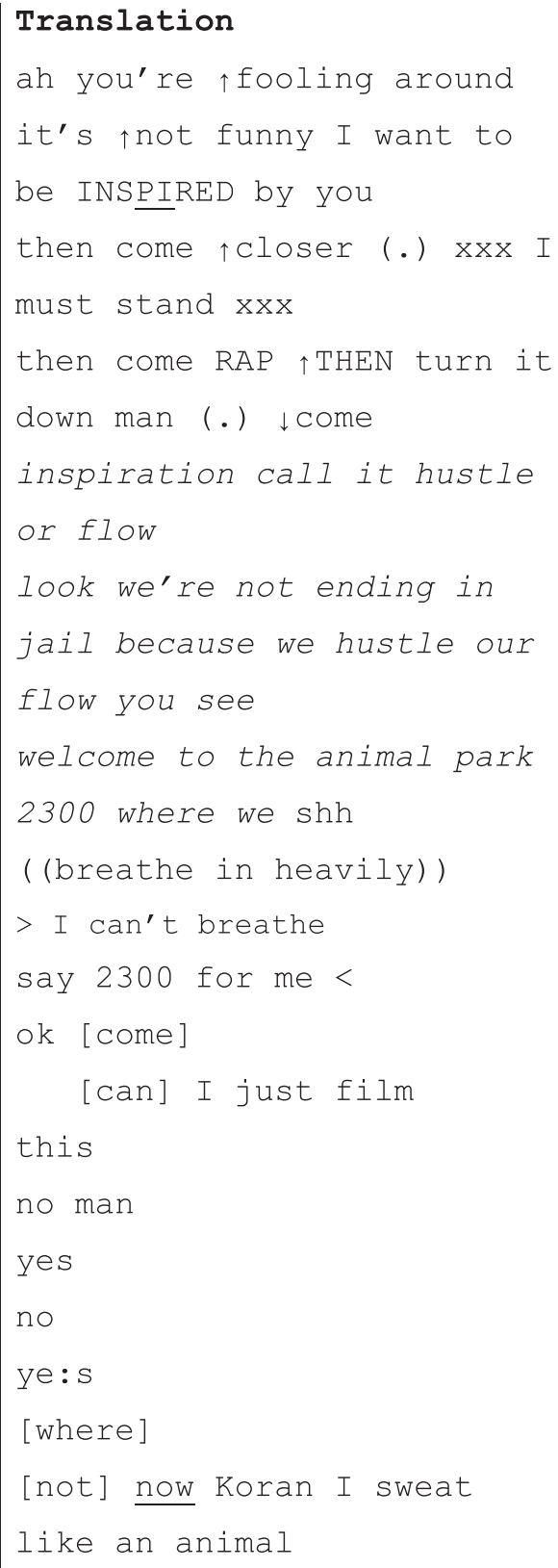


At this occasion in the studio, Bashaar has several times expressed annoyance with having to spend time on the other's rerecordings. Here he reacts to Isaam's failed attempt by criticising him for 'fooling around' and urging him to get it done. Isaam raps (line 7-13) until he is out of breath and has to stop again. The lyrics he performs in this sequence includes the English expressions 'hustle' and 'flow', but are apart from that standard Danish and contain the message of not going to prison as well as a reference to the postal code of the boys' local neighbourhood (2300). Bashaar's utterances are all pronounced with an intonation characteristic of the 'street language'. In line 15 the rap mentor asks if he can film the activity (to document their work on Facebook). Yet, Isaam resist this with the explanation that he sweats 'like an animal'. This utterance directed at the mentor is like Bashaar's contributions spoken with 'street-language' intonation and it includes the expression 'Koran' used as an intensifier - also a feature indexical of the urban speech style. Apart from illustrating how concerns about online presentations were closely interwoven with the offline rap activities, the excerpt also shows how the urban speech style is used in the everyday interaction around rap-music making with the mentor.

Excerpt 4 and 5 are just short examples, but they illustrate a typical linguistic behaviour of the boys. Our interactional data overall documents that features of the 'street-language' style was widely used by the adolescents in interactions with peers, during rap-activities, with their rap mentors and also when doing homework or bragging about school results (as we saw in excerpt 4). Hence, even though we have established that formal educational progress was an important part of the young rappers everyday life, and that they understood their rap-activities as closely linked to education, there is nothing about their everyday interactions suggesting that the adolescents oriented strongly to an ideology equating educational progress with standard language. So is the explanation for the preference for standard linguistic practices in the rap music related to normative orientations of the mentors?

The excerpt 7 from Andreas' notes from a field trip to the suburban youth club suggests that Sufi to some extent displays distance to the everyday speech practices of the participants:

Excerpt 7: 'That stuff about paki language'

[...] after a while he [Sufi] asks what I do. I explain briefly about language. He interrupts and says 'that stuff about paki language ethnolect' and 'have you heard the language they speak at Amager'. I don't get change to answer, because Bashaar says 'yes he knows all the words, we can't hide anything from him anymore' and laughs (Field diary, Andreas, 23rd of March 2011, our translation).

The field diary describes how the mentor ascribes certain linguistic practices to the participants (and not to himself) and labels these 'paki language ethnolect'. The reaction of Bashaar treats the researcher's access to the speech style as requiring explanation, and the local construction of the style documented here involves associations with ethnicity, a particular urban area and unintelligibility. This suggests that the boys' vernacular speech practices are treated as somewhat peculiar.

In 2014 Isaam has become a rap teacher himself, and in a retrospective interview Lian asked him about whether they were taught about choice of linguistic style in their rap music by their mentors, and how he approaches language in his own teaching. He explains that he advices his own rap pupils to only occasionally use what he refers to as 'perkerdansk' ('paki Danish') and otherwise stick to 'ethnic Danish' (in the meaning 'the Danish spoken by ethnic majority Danes'). The reason for this is a concern with the recipients of the music, as he continues to explain: 'yes you should try to get to people to listen [to] your music (.) so you so (.) but let's say for example (.) ah but it's some paki kids making that music we don't want to listen to that (.) but if you can get to the ethnic Danes themselves and [they] think it's cool then you have success' (Isaam, retrospective interview with Lian, February 2014, our translation). According to Isaam the considerations about linguistic style are related to ambitions of success as rappers, and that involves reaching a wider audience and not being rejected as a 'paki kid'. Isaam further explains that in particular their teachers in Ghetto Gourmet often corrected their grammar and sought to teach them linguistic correctness. When Lian asked why, he answered: 'because one shouldn't sound like a stupid (.) like an uneducated person you know (.) because then your text or your message becomes unserious (.) and it's important to get your message out' (Isaam, retrospective interview with Lian, February 2014, our translation). So in addition to aiming at a wider outreach and at artistic success there is a concern with coming across intelligent to be taken seriously. Isaam explains that he is trying to create a new rap association independent of the youth clubs and with its own facilities, and that his main aim with this is to create an environment for the local youth with interest in rap to become skilled and successful as rappers. So whereas it can be alluring to explain the dominance of linguistic standard practices in the rap productions as linked to the ideologies of education, Isaam's accounts point to rap cultural ambitions as an important part of the explanation.

\section{Conclusion}

In this article we have focused on how a group of young rappers in Copenhagen express their popular cultural affiliation with rap music in YouTube videos, and we have discussed their linguistic practices in rap songs in relation to the ethnographic and sociolinguistic context of their musical activities. We have shown that the adolescents employed indexical signs stereotypically associated with different cultural models (e.g. formal school marks and linguistic vernacular style) in peer interactions around rap. However, we observed that vernacular and hybrid linguistic practices that were widely enregistered as streetwise were reduced in the musical productions they shared on social media as the boys became involved in local rappolitical initiatives. Educational aspects were clearly central to the activities in this local rap community. The mentors provided advice and guidance in relation to rap-related skills such as composing, producing and performing, but both on the levels of ideology and practice there were also links to more official schooling. The participants expressed an understanding of 
their rap activities being closely related to progress in formal education. In addition, one of the mentors' own rap texts, for instance, appeal to knowledge as a significant capital, and Isaam in the retrospective interview describes this mentor as strongly involved in the boys' educational development (helping with homework and urging them to get an education). Furthermore, the activity of teaching poetry workshops through the medium of rap in schools exemplified a very direct engagement with formal education.

This focus on education and Isaam's accounts of the importance of linguistic correctness to be taken seriously and avoid appearing uneducated suggest that the preference for standard linguistic practices in the rap productions relate partly to the influence of hegemonic language ideologies of standard and correctness signalling intelligence. But the dominance of standard-linguistic practices in the rap productions was also, according to Isaam, related to adaption to the Danish majority population to achieve success as musicians. The standard adaption we find in our rap data indeed contrasts with global hip hop that is closely associated with African American English and with the general tendencies to use non-standard, hybrid and 'limitless'(Alim, 2011) linguistic practices in hip hop documented in the sociolinguistic studies of hip hop (Androutsopoulos and Scholz, 2003; Pennycook, 2007) and the work within the critical hip hop pedagogies (Hill, 2009; Alim et al., 2009). Linguistically the local rap community is not counter-hegemonic, and rather than bringing linguistic indexes of minority status and youth culture to the front stage, the young rappers assimilate to linguistic majority terms, in the name of success and intelligence.

Sociolinguistic studies in tune with the current focus on globalization and the polycentric communicative conditions it entails (Blommaert and Rampton, 2011; Blommaert, 2010), increasingly attend to CMC as a research site. Our study shows in line with much of this research as Varis and Wang (2011, p. 75) phrase it: that 'Global cultures, codes and flows [...] are not swallowed without chewing' (see also Pennycook, 2007; Stæhr, 2014b). Appropriation of global cultural flows are regulated by local norms and meaning making. This is certainly the case in the context we study, were hip hop culture is understood within the local frame of rap-political and educational activities. We hope to have shown that there is a case to make for ethnography in relation to sociolinguistic studies of CMC. To understand why standard linguistic practices with cultural up-scale indexicality make sense in a rap tune on YouTube, and how one can be a streetwise rapper in Copenhagen, but make use of speech practices enregistered as 'integrated', we need the knowledge of how the hip-hop culture is 'chewed' in this specific context.

\section{Acknowledgements}

We are grateful to the Danish Research Council for Culture and Communication, the Department of Scandinavian Studies and Linguistics and the LANCHART center at the University of Copenhagen for making the research reported in this article possible. We are indebted to the young rappers, their teachers, their rap mentors and the school principal for their keen participation in our project. Our research depends strongly on collaboration with our colleagues in Copenhagen, and we are particularly thankful to Martha Sif Karrebæk, Janus Spindler Møller, Thomas Nørreby, Astrid Ag and Lamies Nassri for fruitful cooperation during fieldwork and discussions of data. Last, but not least, the inspiration and guidance from Jens Normann Jørgensen, whom we sadly lost in 2013, has been invaluable to us in building up our research collaboration and far beyond.

\section{Appendix. Transcription symbols used}

$\begin{array}{ll}\text { Transcription: } & \\ \text { [overlap] } & \text { overlapping speech } \\ \text { LOUD } & \text { louder volume than surrounding utterances } \\ \text { Xxx } & \text { unintelligible speech } \\ \text { (questionable) } & \text { parts uncertain about } \\ ((\text { comment)) } & \text { transcriber's comments } \\ : & \text { prolongation of preceding sound } \\ \uparrow \downarrow & \text { local pitch raise and fall } \\ (.) & \text { short pause } \\ (0.6) & \text { timed pause } \\ \text { Stress } & \text { stress } \\ \text { hhh } & \text { laughter breathe }\end{array}$

\section{References}

Ag, A., Jørgensen, J.N., 2013. Ideologies, norms, and practices in youth poly-languaging. Int. J. Biling. 17 (4), $525-539$.

Agha, A., 2003. The social life of cultural value. Lang. Commun. 23 (3-4), 231-273.

Agha, A., 2007. Language and Social Relations. Cambridge University Press, Cambridge.

Androutsopoulos, J., 2003. Hip Hop: Globale kultur, likale praktiken. Transcript, Bielefeld.

Androutsopoulos, J., 2006. Online hip hop culture. In: Steinberg, S., Parmer, P., Richard, B. (Eds.), Contemporary youth culture. An international encyclopaedia, vol. 1. Greenwood Press, Westport, CT, pp. 217-233. 
Androutsopoulos, J., 2007. Style online. Doing hip hop on the German-speaking web. In: Auer, P. (Ed.), Style and Social Identities. Alternative Approaches to Linguistic Heterogeneity. de Gruyter, Berlin, New York, pp. 279-317.

Androutsopoulos, J., Scholz, A., 2003. Spaghetti funk: appropriation of hip-hop culture and rap music in Europe. Pop. Music Soc. 26, 463-480.

Androutsopoulos, J., 2008. Potentials and Limitations of Discourse-centered Online Ethnography. Language@Internet 5, article 9.

Androutsopoulos, J., 2009. Language and the three spheres of hip hop. In: Alim, H.S., Ibrahim, A., Pennycook, A. (Eds.), Global Linguistic Flows. Hip Hop Cultures, Youth Identities and the Politics of Language. Routledge, New York, pp. 43-62.

Androutsopoulos, J., 2013. Online data collection. In: Mallinson, C., Childs, B., Herk, G.V. (Eds.), Data Collection in Sociolinguistics. Methods and Applications. Routledge, New York.

Alim, H.S., Ibrahim, A., Pennycook, A., 2009. Global Linguistic Flows. Hip Hop Cultures, Youth Identities and the Politics of Language. Routledge, New York.

Alim, H.S., 2011. Global ill-literacies: hip hop cultures, youth identities and the politics of literacy. Rev. Res. Educ. 35, 120-147.

Blackledge, A., Creese, A., 2010. Multilingualism. A Critical Perspective. Continuum, London.

Blommaert, J., 2007. Commentary: on scope and depth in linguistic ethnography. J. Sociolinguist. 11 (5), $682-688$.

Blommaert, J., 2010. The Sociolinguistics of Globalization. Cambridge University Press, Cambridge.

Blommaert, J., Rampton, B., 2011. Language and superdiversity: a position paper. Diversities 13 (2), 1-22.

Bucholtz, M., 1999. You da man: narrating the racial other in the production of white masculinity. J. Sociolinguist. 3 (4), $443-460$.

Coupland, N., 2007. Style. Language Variation and Identity. Cambridge University Press, Cambridge.

Cutler, C., 1999. Yorkville crossing: a case study of hip-hop and a the language of a white middle class teenager in New York City. J. Sociolinguist. 3 (4), 428-442.

Cutler, C., 2007. Hip-hop language in sociolinguistics and beyond. Lang. Linguist. Compass 1 (5), 519-538.

Ellison, N.B., Steinfield, C., Lampe, C., 2007. The benefits of facebook "friends": social capital and college students use of online social network sites. J. Computer-Med. Commun. 12 (4) article 1.

Hill, M.L., 2009. Beats, Rhymes and Classroom Life. Hip-hop Pedagogy and the Politics of Identity. Teacher College Press, New York.

Ito, M., Baumer, S., Bittanti, M., boyd, d., Cody, R., Herr-Stephenson, B., Horst, H., Lange, P., Mahendran, D., Martínez, K., Pascoe, C., Perkel, D., Robinson, L., Sims, C.,

Tripp, L., 2010. Hanging Out, Messing Around, and Geeking Out: Kids Living and Learning with New Media. The MIT Press, Cambridge, Massachusetts.

Jaspers, J., 2011. Strange bedfellows: appropriations of a tainted urban dialect. J. Sociolinguist. 15 (4), $493-524$.

Jørgensen, J.N., 2008. Poly-lingual languaging around and among children and adolescents. Int. J. Multiling. 5 (3), $161-176$.

Jørgensen, J.N., 2010. Languaging. Nine Years of Poly-lingual Development of Turkish-Danish Grade School Students. vol. 1-2. In: Copenhagen Studies in

Bilingualism, vol. K15-K16. University of Copenhagen, Copenhagen.

Jørgensen, J.N., Karrebæk, M., Madsen, L.M., Møller, J.S., 2011. Polylanguaging in superdiversity. Diversities 13 (2), 23-38.

Kristensen, K., 2003. Standard Danish, Copenhagen sociolects, and regional varieties in the 1900s. Int. J. Sociol. Lang. 159, $29-44$.

Kristiansen, T., 2009. The macro-level social meanings of late modern Danish accents. Acta Linguist. Hafniensia 41, 167-192.

Kristiansen, T., Jørgensen, N.J., 2003. The sociolinguistics of Danish. Int. J. Sociol. Lang. 159, 1-7.

Larsen, M.C., 2009. Sociale netværkssider og digital ungdomsskultur. MedieKultur 47 article 45.

Lee, C.K.M., 2011. Micro-blogging and status updates on Facebook. Texts and practices. In: Thurlow, C., Mroczek, K. (Eds.), Digital Discourse: Language in the New Media. Oxford University Press, Oxford, pp. 110-128.

Leppänen, S., Häkkinen, A., 2012. Buffalaxed superdiversity: representations of the other on YouTube. Diversities 14 (2), $17-33$.

Li, J., Juffermans, K., 2011. Multilingual Europe 2.0: Dutch-Chinese Youth Identities in the Era of Superdiversity. Working Papers in Urban Language and Literacies, paper 71. King's College London, London.

Livingstone, S., 2008. Taking risky opportunities in youthful content creation: teenager's use of social networking sites for intimacy, privacy and selfexpression. New Media Soc. 10 (3), 393-411.

Madsen, L.M., 2011. Interactional renegotiations of educational discourses in recreational learning contexts. Linguist. Educ. 22 (1), 53-68.

Madsen, L.M., 2013. 'High' and 'low' in urban Danish speech styles. Lang. Soc. 42 (2), 115-138.

Madsen, L.M., 2015. Rap music, education and discourses on integration. In: Madsen, L.M., Møller, J.S., Karrebæk, M.S. (Eds.), Everyday Languaging. Trends in Applied Linguistics. Mouton de Gruyter (in press).

Madsen, L.M., Jørgensen, J.N., Møller, J.S., 2010. “Street Language” and “Integrated”: Language Use and Enregisterment Among Late Modern Urban Girls. In: Copenhagen Studies in Bilingualism, vol. 55. University of Copenhagen, Copenhagen, pp. 81-113.

Madsen, L.M., Karrebæk, M.S., Møller, J.S., 2013. The Amager project: a Study of Language and Social Life of Minority Children and Youth. Tilburg Papers in Culture Studies, paper 52.

Madsen, L.M., Karrebæk, M.S., 2015. Urban classrooms, polycentricity and sociolinguistic resources. In: Shaw, S., Copland, F., Snell, J. (Eds.), Linguistic Ethnography: Interdisciplinary Explorations. Palgrave (in press).

Maegaard, M., 2007. Udtalevariation og - forandring i københavnsk - en etnografisk undersøgelse af sprogbrug, sociale kategorier og social praksis blandt unge på en københavnsk folkeskole. Nordisk Forskningsinstitut, Copenhagen.

Miller, V., 2008. New media, networking and phatic culture. Converg. Int. J. Res. New Media Technol. 14 (4), $387-400$.

Miller, C., Shephard, D., 2004. Blogging as social action: a genre analysis of the weblog. In: Gurak, L., Antonijevic, S., Johnson, L., Ratliff, C., Reyman, J. (Eds.), Into the Blogosphere. Rhetoric, Community, and Culture of Weblogs. Creative Commons. University of Minnesota. http://blog.lib.umn.edu/blogosphere/ blogging_as_social_action.html.

Morgan, M., 2002. Reading between the Lines: Language, Discourse and Power in African American Culture. Cambridge University Press, Cambridge.

Møller, J., 2009. Poly-lingual Interaction across Childhood, Youth and Adulthood. University of Copenhagen, Copenhagen.

Møller, J.S., Jørgensen, J.N., 2013. Organizations of language among adolescents in superdiverse Copenhagen. Int. Electron. J. Element. Educ. 6 (1), $23-42$.

Ochs, E., 1992. Indexing gender. In: Duranti, A., Goodwin, C. (Eds.), Rethinking Context: Language as an Interactive Phenomenon. Cambridge University Press, Cambridge, pp. 335-358.

Pedersen, I.L., 2009. The social embedding of standard ideology through four hundred years of standardisation. In: Maegaard, M., Gregersen, F., Quist, P. Jørgensen, N.J. (Eds.), Language Attitudes, Standardization and Language Change. Novus Press, Oslo, pp. 51-68.

Pennycook, A., 2007. Global Englishes and Transcultural Flows. Routledge, Abingdon.

Rampton, B., 2006. Language in Late Modernity. Interaction in an Urban School. Cambridge University Press, Cambridge.

Rampton, B., Tusting, K., Maybin, J., Barwel, R., Creese, A., Lytra, V., 2004. UK linguistic Ethnography: a Discussion Paper. http://uklef.net/documents/papers/ ramptonetal2004.pdf.

Rymes, B., 2012. Recontextualizing YouTube. From macro-micro to mass-mediated communicative repertoires. Anthropol. Educ. Q. 43 (2), $214-227$.

Silverstein, M., 2003. Indexical order and the dialectics of sociolinguistic life. Lang. Communic. 23, 193-229.

Stæhr, A., 2010. 'Rappen Reddede os'. Et Studie af Senmoderne Storbydrenges Identitetsarbejde i Fritids- og Skolemiljøer København, Københavnerstudier i Tosprogethed, Bind 54. Københavns Universitet, Copenhagen.

Stæhr, A., 2014a. Metapragmatic Activities on Facebook. Enregisterment across Written and Spoken Language Practices. Working Papers in Urban Language \& Literacies, paper 124 .

Stæhr, A., 2014b. Appropriation of transcultural flows among Copenhagen youth - the case of Illuminati. In: Androutsopoulos, J., Juffermans, K. (Eds.), Digital Language Practices in Superdiversity, Discourse, Context \& Media, vols. 4-5.

Stylianou, E., 2010. Keeping it Native (?): the conflicts and contradictions of cypriot hip hop. In: Terkourafi, M. (Ed.), Languages of Global Hip Hop. Continuum, London, pp. 194-222.

Sørensen, A.S., 2012. Facebook - selvfremstilling, smalltalk og social regulering. MedieKultur 52, 132-152.

Terkourafi, M. (Ed.), 2010. Languages of Global Hip Hop. Continuum, London.

Varis, P., Wang, X., 2011. Superdiversity on the internet: a case from China. Diversities 13 (2), 71-83. 
Andreas Stæhr, postdoc, LANCHART center. PhD (2011-2014) on language social media. Main research interests: Language and social media, peer-cultural activities and language use across online and offline contexts, popular culture, linguistic diversity, social positioning among youth in multicultural urban settings, socialization, linguistic and social normativity. Publications in Language Variation and Change, Discourse Context and Media and in an international edited volume of language and super-diversity.

Lian Malai Madsen, Associate Professor, Dep. of Scandinavian Studies and Linguistics. PhD (2008) and postdoc research (2009-2012) on linguistic and social practices in school and leisure contexts among youth. Main research interests: linguistic diversity, social positioning among youth in multicultural urban settings, stylization, peer-cultural activities in relation to language use, socialization and education. Publications in Int. Journal of Multilingualism, Linguistics and Education and Language in Society and in international edited volumes on sports, integration \& societal cohesion, heteroglossia and European urban youth language. Forthcoming book with Multilingual Matters. Member of the steering committee of Linguistic Ethnography Forum. 